\title{
Guest editorial: What democracy looks like
}

\author{
Jane L. Collins
}

Published online: 9 June 2011

(C) Springer Science+Business Media B.V. 2011

Greetings from Wisconsin, 3 months into what some have tagged our "Main Street Rebellion." A couple of weeks ago, I found myself sitting in a messy, airless room above a coffee shop, poring over Republican-filed petitions to recall Democratic senators. We were perusing the handiwork of out-of-state canvassers who had entered long lists of names from the phone book, including an entry for State Assembly Representative Mark Pocan's father, who has been dead for 20 years. Other volunteers were out in the streets collecting affidavits from people who had signed the petitions because they were told they demanded the recall of Governor Scott Walker. Republicans were contesting the validity of six recall petitions filed by Democrats against Republican senators-on the grounds that the petitioners' names were not included on all pages of the document. Three blocks away from the coffee shop office, teams of citizen observers watched the recount of ballots from the recent State Supreme Court election. Looking up from a pile of petitions, a fellow volunteer plaintively turned the movement's pervasive tag-line into a question: "This is what democracy looks like?"

How did we get to this point? And what does it say about the prospects for grassroots movements targeting corporate power and defending labor rights and social spending? These are questions I have been asking myself incessantly since February. Here is an attempt to recap the, "How did we get here" question. In February and March of this year, public sector workers and their friends and neighbors took to the streets in Wisconsin. A few months earlier, perhaps in a fit of pique at the bad news of the recession, our state had elected a Republican governor and Republican majorities in both legislative houses. The governor, Scott Walker, had campaigned as a moderate but soon revealed himself to be at the cutting edge of the Tea Party agenda. The massive demonstrations that began February 14th were

\footnotetext{
J. L. Collins $(\bowtie)$

Department of Community \& Environmental Sociology, University of Wisconsin,

Madison, WI, USA

e-mail: jcollins@ssc.wisc.edu
} 
ignited by the unveiling of a malicious "Budget Repair Bill" that stripped collective bargaining rights from public sector employees, home health aides, and daycare workers, while imposing new rules on public sector unions that will make it impossible for them to survive. (Similar bills have now been introduced or passed in at least 12 other states). In the months that followed, the governor released a harsh and socially regressive budget while our legislature churned out a steady stream of laws and policies that concentrated power in the governor's hands, dismantled regulations across the economy, gave Wisconsin the most restrictive voting laws in the country, and brutally cut social programs-from recycling and public transportation to medical assistance and schools.

In response to this aggressive right-wing agenda, beginning on February 15th, teachers across the state called in sick and protesters began showing up at the Capitol-initially 10,000 of them, then 20,000, building to 70,000 on February 19 and 150,000 on March 12th. Despite the snow and intense cold, a broad swath of the community came out to support public workers, including police officers and firefighters, teamsters and steelworkers, immigrant workers, and faith communities. With protesters chanting, "this is what democracy looks like," and, "Recall Walker," accompanied by bagpipes and cowbells, earnest signs and street theater, the Capitol square became a fragile but intense political field. The presence of people in the Capitol seeking to testify before the legislature's Joint Finance Committee evolved into a kind of friendly occupation as the University of Wisconsin's Teaching Assistant's Association organized the protesters' care and feeding. Thousands chanted and drummed, sang and gave speeches through daylight hours and firefighters and steelworkers, teachers and students slept next to each other on the Capitol floor at night. Bob Lafollette's statue became a kind of shrine.

This is the part of the story that captured the public imagination-the narrative of working classes (in the media's parlance "Main Street") finding their voice and speaking back to austerity politics; the images of stalwart Midwestern families standing in the snow. The mainstream media gave some coverage to the protests (Fox slipped in some footage of violent altercations-with palm trees in the background giving away the fact that they were not filmed in Madison). A blogger impersonating David Koch — a billionaire rightist Republican contributor-made a phone call to our governor that revealed how profoundly his agenda was shaped by interests outside the state. But the struggle could not stay in the streets forever. Even as the weather warmed, the momentum shifted to crucial but less photogenic contexts: the courts, the spring elections for a new state Supreme Court Justice, recall campaigns and the battle over the budget. Walker succeeded in clearing protesters from the Capitol (the Madison, Dane County, and Capitol police departments refused to remove them, so the governor called in the State Highway Patrol. Now, for the first time in state history, people must pass through a metal detector and police inspection to enter the Capitol). The legislature passed the hated budget repair bill on the night of March 9th, without proper notice, leading to court challenges that still have not been resolved.

What do these unfolding events tell us about the prospects for an ongoing grassroots movement? The protests in Wisconsin owed a great deal to the theoretical and strategic groundwork laid by community-based labor movements in the global South and imported into the United States by immigrant workers in unions like the 
SEIU and UNITE/HERE, as well as to the global justice movement's innovations in organizing loose networks of protesters around specific projects without a single leader. Wisconsin has the kind of civic infrastructure that could put people in the streets (the South-Central Federation of Labor, which brings together the region's unions; the 50 year old School for Workers; the Center on Wisconsin Strategy; the Interfaith Coalition for Worker Justice; and the Teaching Assistants' Association to name a few groups and organizations). As the momentum shifted from the Capitol square to the more mundane tasks of mounting the recall campaigns, there has been a tendency for people to work more and more through their unions, or the Democratic Party's grassroots groups. Some wholly new organizations have formed to foster cross-fertilization and collaboration in pursuit of particular goals, for example, publication of an alternative "people's budget." But the question of what the long-term movement is going to look like is still up in the air.

One of the most unanticipated aspects of the movement to date is its broad base - the way that an attack on the public sector has reverberated through-not just all the unions in the state-but the state's working classes. Entire communities are pulling together, both to protect what they understand to be the economy's "last good jobs" and also to protect the services that those public workers provide to the community. The outpouring of anger in response to the right-wing onslaught of the last months and the sustained, but less glamorous, efforts to turn things around that are still underway, took all of us by surprise.

Like recent uprisings in Cairo and Tunisia, the movement that has emerged in Wisconsin has labor at it is center, but it is not a labor movement. What is happening in Wisconsin is in many ways an anti-corporate struggle. It responds to a corporate power grab that was made possible by the US Supreme Court's Citizens United decision in 2010, which gave corporations virtually unlimited power to finance electoral campaigns. This new corporate clout tipped the scales in the fall 2010 gubernatorial and state-level elections around the country as well as in races for the US House of Representatives. As newly elected governors set about doing the bidding of their corporate donors, they unleashed a backlash from the populace. That backlash joins workers who will lose rights with the elderly, the disabled, farmers, and the poor, all of whom will lose state medical assistance, and with the unemployed and working poor who will lose access to many other forms of state support. It mobilizes vast numbers of people fighting what David Harvey calls, "accumulation by dispossession" (although they do not know it by that name). These are people who believe that certain services (roads, fire and police protection, garbage collection, schools, and public transportation) are best provided for collectively and who do not want to lose them or see them privatized. This reclaiming of civic space, labor rights, and collective investments is not confined to Wisconsin, but is unfolding today in almost every state in the United States. While the popular movements in the Middle East and North Africa in 2011 challenge distinct configurations of power (distinct from those in the US context and distinct from each other), I believe that the rights, civic space, and collective goods they seek to reclaim are in many ways the same. All of us face the challenge of channeling the outrage (and public playfulness) of street protests into the kind of longrange strategies that can derail the agendas of despotic actors and reclaim power for popular classes. 